\title{
Ситуация успеха как средство воспитания ребенка из неблагополучной семьи
}

\author{
Куличкина С.А., студентка, \\ Вилюйский педагогический колледж имени Н.Г. Чернышевского \\ E-mail: ivanovna06@mail.ru
}

Научный руководитель: к.n.н. Борисова 3.H.

Деформация личности под влиянием семьи, ее психологической неустойчивости начинается с раннего детства. Именно на этой стадии под влиянием неблагоприятных факторов возникают вредные для дальнейшего развития ценностные установки.

Если в семье нет гармонии чувств, если не создана нравственная атмосфера, если взрослые подвержены низменным человеческим страстям, то развитие личности осложняется, семейное воспитание из положительного становится отрицательным фактором формирования личности. Будущему учителю важно овладеть теорией и практикой воспитательной работы с детьми из неблагополучных семей. Из теории педагогики известно, что благополучное личностное развитие ребенка возможно при наличии у него ситуации успеха: если не в учебе, то в развитии, хотя бы, каких-либо способностей. Вот почему мы взяли тему «Ситуация успеха как средство воспитания ребенка из неблагополучной семьи».

Цель: Проверить эффективность ситуации успеха как средства воспитания ребенка из неблагополучной семьи. Объект: проблемы социализации ребенка в неблагополучных общественных условиях, в частности, в семье, предмет - ситуация успеха как средство воспитания ребенка из неблагополучной семьи.

Мы вынесли следующую гипотезу: Вслед за учеными мы предполагаем, что воспитание ребенка в неблагополучной семье может быть скорректировано, если учитель умеет эффективно использовать ситуацию успеха.

Изучая свою работу, мы познакомились с работами таких ученых как Л.С. Выготский, В.В. Зикратов, Г.П. Бочкарева, М.А. Галагузова, В.М. Целуйко, М.И. Буянов, А.С. Белкин.

В последнее время прослеживается тенденция увеличения числа детей, лишенных родительского попечения, растет количество несовершеннолетних, вовлеченных в преступную деятельность, хранение и употребление наркотиков, произошел резкий всплеск беспризорности и безнадзорности несовершеннолетних. В связи с этим педагогам необходимо обратить внимание на детей из неблагополучных семей, организовать такую воспитательную работу, где бы они смогли самоутвердиться в глазах сверстников.

В современном обществе неблагополучная семья рассматривается как фактор жизненного риска ребенка. Неблагополучие в семье ведет к психической травматизации детей, агрессивности, дисбалансу в сфере общения, увеличению числа правонарушителей, педагогической запущенности.

Большая часть усвоенного детьми в семье опыта жизни переходит в подсознание. Подсознательная программа заложенная в человеке семьей, действует в течение всей жизни и формирует жизненные цели, определяет устои, убеждения, ценности, умение выражать чувства. Проживание ребенка в неблагополучной семье приводит к снижению 
у ребенка эмпатии - способности понимать других и сочувствовать им, а в некоторых случаях и к эмоциональной "глухоте".

Переживание успеха внушает ребенку уверенность в собственных силах. Появляется желание вновь достигнуть хороших результатов, возникает ощущение внутреннего благополучия, что, в свою очередь, благотворно влияет на общее отношение ребенка к окружающему миру. Даже разовое переживание успеха может коренным образом изменить ритм психологического самочувствия ребенка, изменить стиль его деятельности, взаимоотношений с окружающими. Ситуация успеха может стать своего рода спусковым механизмом дальнейшего движения личности.

Использование метода создания ситуации успеха в социально-педагогической деятельности необходимо. Так как успех формирует позитивную самооценку, а известно, что люди с положительной самооценкой терпимее относятся к окружающим, им легче справляться с трудностями.

В практической части мы провели:

1. Среди однокурсников мы провели анонимный опрос с целью узнать: есть ли студенты из неблагополучных семей. Мы использовали следующий опросник:

1. Как вы считаете, есть ли на сегодня у вас нерешенные проблемы?

2. Какую семью вы считаете благополучной?

3. Хотели ли вы жить в благополучной семье?

4. Как вы думаете, повлияла ли ваша семья на то, что вы сегодня есть такой (такая)?

Из шести ответивших утвердительно ответили на наши вопросы:

- четверо имеют личностные проблемы (по их же словам);

- двое пишут, что всегда завидовали детям из нормальной семьи;

- 50\% уверены, что были бы другими людьми, если бы росли в нормальной семье.

2. В период 10 марта по 15 марта 2011 г. нами была пройдена внеклассная воспитательная практика в школе ВСОШ №3 им. Н.С.Степанова. Практику проходили во 2 «а» классе, классный руководитель Мальцева Луиза Романовна, где сплоченный коллектив, заинтересованные, очень активные дети.

Нами в качестве практического исследования проведено:

1. В первый день мы провели собеседование с детьми. Оказалось, что по социальному положению большинство детей из среднеобеспеченных семей, но и есть дети из малоимущих. Эти дети в анкете написали, что хотели бы жить в большом красивом доме.

В этом классе мы исследовали двоих детей из неблагополучной семьи.

1. Для первого, назовем его Андрей, характерна повышенная неорганизованность, ребенок не имеет интереса к уроку, учится посредственно. Нет интереса, любознательности. У него по его словам нет игрушек, книг и т.д. Явно отстает от сверстников по общему развитию.

2. Для второй, Саскыланы, которая живет под опекой родной тети, характерна повышенная агрессивность. Но у нее есть хороший интерес к учебе. Однако, она когда захочет, проявляет агрессивность, например, может очень просто отобрать контрольную работу и списать. Всегда активна на уроке. Замечена в воровстве денег. То есть, уже есть тенденция к нарушению поведения.

Проведенное исследование нам помогло выявить: 
1. С каждым годом социально неблагополучных семей становится больше. Следовательно, будущему учителю важно изучать формы, средства и способы работы с неблагополучными детьми и их семьями.

2. По исследованиям Н.С. Лейтес, Ю.Д. Бабаевой и др. а также по нашим наблюдениям, модель поведения родителей, дети так или иначе перенимают и повторяют во взрослой жизни.

3. Как показала практика, в силу индивидуальных различий учащиеся по-разному реагируют на предложенные учителем ситуации. Для некоторых школьников ситуация успеха должна быть повторена неоднократно, до тех пор пока не реализуется основная задача: ученик испытает чувства удовлетворения не только от итога деятельности, но и от самого процесса овладения знаниями. Поэтому учителю важно создавать атмосферу доверия в отношениях с учеником.

4. Если мы хотим сформировать у школьников стремление к достижениям, то надо сделать так, чтобы они знали, каких результатов мы ждем от них, по каким показателям будем оценивать их работу, а также были уверены в том, что все наши действия будут объективными и справедливыми.

Таким образом, поставленная гипотеза подтверждается: что за годы жизни в неблагополучной семье большинство детей успевает приобрести огромный опыт асоциального поведения, психологически сломаться, утвердиться в таком варианте жизненного самоопределения, которое противоречит нормам общества.

\section{Список литературы:}

1. Кон И.С. Ребенок и общество. - М.: ИЦ «Академия», 2008. - 216 с.

2. Мид М. Культура и мир детства. - М., 2007.

3. Шапиро Б.Ю. Психология семейных отношений: Программа курса. М.:ВЛАДОС, 2002.

4. Буянов М.И. Ребенок из неблагополучной семьи: записки детского психолога. - М.: ИЦ «Академия», 2003. - 189с.

5. Возрастная и педагогическая психология. Под ред. Гамезо. - М.: Наука. 1984 г. $-156 \mathrm{c}$.

6. Габай Т.В. Педагогическая психология: Учеб. пособие для студ. высш. учеб. заведений. - М.: Академия, 2003. -240 с.

7. Москаленко В. Ребенок из семьи алкоголика // Воспитание школьника. - 1999. - №1. - C. 24-26.

8. Немов Р.С. Психология: В 3-х т. Т.2. - 4-е изд. - М.: ВЛАДОС, 2001. - 608 с.

9. Психология и педагогика / Сост. А.А.Радугин. - 2-е изд., испр. и доп. - М.: Центр, 1999. - 256 с. 